\title{
STRUCTURE AND TEMPORAL VARIATION OF TREMATODE AND GASTROPOD COMMUNITIES IN A FRESHWATER ECOSYSTEM
}

\author{
GÉRARD C.*
}

\section{Summary:}

The infra- and component community dynamics of digenetic trematodes in a freshwater gastropod community were examined over a 33-month period. The gastropod and trematode communities were composed of 17 and 10 species respectively. A total of 9,831 snails was collected; among them, 192 belonging to 14 species were infected by larval trematodes. The size of infected snails was significantly greater than that of healthy ones, and the increase of prevalence with size/age was interpreted as related to the increased probability of ultimately becoming parasitized. The trematode community was rich in allogenic species, but the most frequent trematode (cercariaeum) was autogenic and generalist (a range of 12 snail host species). There was a significantly positive relationship between the frequency of trematode species in the community and the number of first intermediate host species. A great temporal heterogeneity occurred in the prevalence of the snails, mainly attributed to the great temporal fluctuations of snail host populations and the variability of freshwater ecological conditions. The data on the occurrence of larval trematodes in 14 host species over the 33 month study allowed indicate a significant negative correlation between the abundance of gastropods and the prevalence of trematodes.

KEY WORDS : trematode, gastropod, communities, dynamics, hostparasite interactions.

\section{INTRODUCTION}

$\mathrm{H}$ ost-parasite interactions and their consequences on population dynamics and community structure of free-living organisms have been the subject of numerous theoretical studies (Anderson \& May, 1978; Holmes, 1982; Keymer et al., 1991), but very few works have demonstrated the regulating impact of parasites in the field (Dobson \& Hudson, 1992; Esch et al., 1997). Investigations on trematode communities in molluscan intermediate hosts

\footnotetext{
*UMR CNRS 6553 "Écobio", Équipe Physiologie et Écophysiologie, Université de Rennes I, Avenue du Général Leclerc, 35042 Rennes Cedex, France.

Tel. : $33(0) 299281444$ - Fax : 33 (0)2 99281612

E-mail : claudia.gerard@univ-rennes1.fr
}

Résumé : Structure et VARIATION temporelle des COMmunautés DE TRÉMATODES ET GASTÉROPODES DANS UN ÉCOSYSTEME DULCICOLE

Afin de mieux comprendre les interactions trématodes-mollusques à l'échelle communautaire, la dynamique des infra- et des xénocommunautés de trématodes digènes d'un lac a été étudiée pendant 33 mois. Les communautés de gastéropodes et de trématodes sont composées de 17 et de 10 espèces respectivement. Au total, 9831 mollusques ont été collectés, parmi lesquels 192, appartenant à 14 espèces différentes, étaient parasités par des formes larvaires de trématodes. Les mollusques parasités sont significativement plus grands que les mollusques sains, et l'augmentation de la prévalence avec la taille/âge peut s'expliquer par la probabilité accrue de devenir parasité. La communauté de trématodes est riche en espèces allogéniques, mais le plus fréquent (cercariaeum) est autogénique et généraliste 112 espèces de gastéropodes hôtes). Une relation positive et significative est mise en évidence entre la fréquence des espèces de trématodes chez les mollusques et le nombre d'espèces de mollusques hôtes. La prévalence des mollusques est très hétérogène dans le temps, principalement en raison des importantes fluctuations temporelles des populations de mollusques hôtes et de la variabilité des conditions écologiques en eau douce. Les données sur la présence des trématodes chez 14 espèces hôtes pendant 33 mois permettent d'établir une corrélation négative et significative entre l'abondance des gastéropodes et la prévalence des trématodes. Les résultats reflètent la complexité des interactions en jeu et leur impact potentiel sur la structure et la dynamique des communautés.

MOTS CLÉS : trématode, gastéropode, communauté, dynamique, interaction hôte-parasite.

have substantially increased in recent years (for reviews : Brown et al., 1988; Esch et al., 1990; Esch \& Fernandez, 1994; Kuris \& Lafferty, 1994). Temporal and life history characteristics of both snail hosts and parasites are known to affect intramolluscan trematode dynamics (Esch \& Fernandez, 1994). In the present study, larval trematodes are considered as a potential ecological force in structuring freshwater gastropod communities. On the one hand, alterations of the physiology and metabolism of freshwater snail hosts by larval trematodes (see Thompson, 1985; Hurd, 1990; De Kock, 1993 for reviews) may have life-history consequences, e.g., effects on growth, fecundity, and survival; on the other hand, parasitism can modify the outcome of competition between two species ("indirect parasite-mediated competition"), in favouring or penalizing the host species or the unparasitized species (Price et al., 1986, 1988; Lozano, 1991). 
The aim of the present work is to better understand the snail-trematode interactions at the community level, and their implications in the temporal structure of gastropod assemblages. The dynamics of all gastropod populations in the ecosystem have been studied in relation to the fluctuations of parasite component communities of larval trematodes.

\section{MATERIALS AND METHODS}

T The study was carried out in the Combourg lake, a pool of shallow stagnant water in Ille-etVilaine, eastern Brittany, France (northern latitude $48^{\circ} 24^{\prime}$, western longitude $1^{\circ} 45^{\prime}$; area $=17 \mathrm{ha}$ ). Snails were collected in a lakeside area $100 \mathrm{~m}$ long, 2,5 $\mathrm{m}$ wide and 1,0 $\mathrm{m}$ maximum depth (sampling area in previous studies (Gérard, 1997)). Collections were made at the end of each month, from September 1996 to May 1999, always in the same way, using a pondnet (nylon mesh: $1 \mathrm{~mm}$, square aperture : $0.5 \times 0.5 \mathrm{~m}$ ) sweeping the column of water in the whole area studied. Each time, water temperature and depth were measured near the shore and $2.5 \mathrm{~m}$ from the shoreline. The pond-net contents were examined in the laboratory. All the collected snails (9,831 individuals) were systematically identified, measured with calipers (precision : $0.1 \mathrm{~mm}$ ) (height for conic shells, diameter for discoid shells), then dissected under a stereomicroscope to record prepatent and patent parasitic infections. The larval trematodes, when present (sporocysts or rediae, and cercariae during the patent period), were observed alive and drawn with the help of a microscope equipped with a camera lucida.

The following parameters determined for gastropods were as follows : shell size, species richness, abundance, frequency (percentage of snails of a species in all gastropods), frequency of occurrence (percentage of months a species is collected in 33 months), number of infected snails, prevalence (percentage of snails harbouring trematodes (Bush et al., 1997)). The parameters used for trematodes were : species richness, number of trematode infrapopulations across all gastropod species, frequency of trematode infrapopulations, host specificity (number of first intermediate host species), frequency of trematode species in each component community. Mean values of data are reported as means \pm standard error (SE).

The effect of gastropod species, trematode parasitism, and their interactions on shell size was tested, using a two-way analysis of variance (ANOVA). A correspondence analysis was applied on a contingency table (Table I) including gastropod species abundances, collective prevalence (all trematodes), water temperature and depth over time (33 months), in order to draw the relationships among them. Species with less than 12 individuals during the 33-month study (Gyraulus acronicus, Segmentina nitida) were not included in the data analysis. A hierarchical clustering based on the trematode component communities was used to determine resemblances between gastropod species. Correspondence analysis and hierarchical clustering were conducted using Stat-Itcf software. The distance between individuals and the aggregation criterion chosen were, respectively, chi-square and weighted clustering ("WPGMA", in Legendre \& Legendre, 1979).

Cricket Graph software was used to establish regressions, and the Spearman coefficient was calculated to determine correlations, on one hand between host specificity, S, and number of infrapopulations of a trematode species, NTI (and also, between $S$ and frequency of infrapopulations of a trematode species, FTI) and, on the other hand, between trematode prevalence per month per host species and snail host abundance.

\section{RESULTS}

\section{STRUCTURE AND ABUNDANCE FLUCTUATIONS OF THE GASTROPOD COMMUNITY}

$\mathrm{T}$ The gastropod community in the Combourg lake was composed of 17 species of prosobranch (Valvatidae) and pulmonate (Planorbidae, Lymnaeidae, Physidae, and Ancylidae) snails (Table II). The Planorbidae had the greatest species diversity (7) and number of individuals $(4,929)$; the planorbid Gyraulus albus was the most abundant species. Four other species were also abundant (>10\%) in the community, Planorbis planorbis, Lymnaea peregra, Physa acuta, and Lymnaea auricularia.

During the 33-month study (Table I), gastropods fluctuated widely in the monthly abundance, ranging from 11 to 4,456 individuals (mean abundance $\pm \mathrm{SE}=298$ \pm 386 per month), whereas the mean species richness was relatively stable ( $8 \pm 1$ species per month). The first two axes of the correspondence analysis appeared relevant and removed $41.3 \%$ of the total variance of the cloud of points, respectively, $21.5 \%$ for F1 and $19.8 \%$ for F2. Three distinct periods were identified, according to the highest relative contributions of the variables about each of the two axes: SeptemberOctober 1996 (explained $42.4 \%$ of the variance of the first axis), November-December 1996 (explained 80.1\% of the variance of the second axis), and May 97 (explained $18.6 \%$ of the variance of the first axis).

In September and October 1996, the time of the first collections, the water level was enormously decreased (depth $\leq 10 \mathrm{~cm}$ ) as a consequence of a severe drought in summer of 1996, with 4-9 $\mathrm{m}$ between the lake mar- 




Valvata cristata

Valvata pulchella

Valvata piscinalis

Lymnaea truncatula

Lymnaea palustris

Lymnaea peregra

Lymnaea auricularia

Lymnaea stagnalis

Gyraulus albus

Gyraulus acronicus

Planorbis planorbis

Planorbarius corneus

Armiger crista

Segmentina nitida

Hippeutis complanatus

Ancylus lacustris

Physa acuta

$0-0-3=0-0$

\begin{tabular}{|c|c|c|c|c|c|c|c|c|c|c|c|c|c|c|c|c|c|}
\hline $\mathrm{P}(\%)$ & & 0.00 & 0.00 & 4.76 & 1.03 & 1.90 & 1.33 & 0.00 & 0.00 & 0.29 & 0.42 & 3.21 & 18.42 & 11.87 & 0.00 & 8.25 & 4.65 \\
\hline $\mathrm{T}\left({ }^{\circ} \mathrm{C}\right)$ & & 12.0 & 14.0 & 6.0 & 5.5 & 5.5 & 10.5 & 11.0 & 15.0 & 16.5 & 17.0 & 22.5 & 24.5 & 17.0 & 10.5 & 8.5 & 8.0 \\
\hline $\bar{D}(\mathrm{~cm})$ & & 5.0 & 10.0 & 20.5 & 42.5 & 43.5 & 38.0 & 47.5 & 54.0 & 30.0 & 34.0 & 27.0 & 28.5 & 23.0 & 34.0 & 41.0 & 46.0 \\
\hline Gastropods & Jan-98 & Feb-98 & Mar-98 & Apr-98 & May-98 & Jun-98 & Jul-98 & Aug-98 & Sep-98 & Oct-98 & Nov-98 & Dec-98 & Jan-99 & Feb-99 & Mar-99 & Apr-99 & May-99 \\
\hline
\end{tabular}

Valvata cristata

Valvata pulchella

Valvata piscinalis

Lymnaea truncatula
Lymnaea palustris

Lymnaea peregra

Lymnaea auricularia

Lymnaea stagnalis

Gyraulus albus

Gyraulus acronicus

Planorbis planorbis

Planorbarius corneus

Armiger crista

Segmentina nitida

Hippeutis complanatus

Ancylus lacustris

$\begin{array}{llllll}2 & 19 & 22 & 31 & 24\end{array}$

Pbysa acuta

\begin{tabular}{|c|c|c|c|c|c|c|c|c|c|c|c|c|c|c|c|c|c|}
\hline P (\%) & 5.00 & 4.80 & 11.00 & 11.59 & 6.67 & 0.00 & 0.00 & 12.00 & 2.13 & 2.63 & 4.12 & 3.88 & 2.33 & 1.10 & 2.78 & 10.00 & 1.22 \\
\hline $\mathrm{T}\left({ }^{\circ} \mathrm{C}\right)$ & 2.0 & 10.0 & 9.5 & 13.5 & 18.5 & 22.0 & 21.0 & 21.0 & 17.0 & 14.0 & 4.0 & 8.5 & 9.5 & 9.0 & 11.0 & 13.0 & 19.5 \\
\hline $\mathrm{D}(\mathrm{cm})$ & 57.3 & 48.4 & 45.0 & 54.3 & 38.8 & 41.3 & 33.4 & 23.1 & 36.5 & 40.8 & 40.4 & 54.0 & 48.8 & 53.0 & 47.0 & 52.1 & 45.3 \\
\hline
\end{tabular}

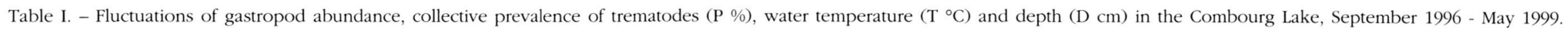


gins and the shore. Due to the drought, few molluscs were collected ( 53 Valvata piscinalis, five L. peregra) and the dominant species during these two months, $V$. piscinalis, explained $55.5 \%$ of the variance of the first axis and represented $1.31 \%$ of the total number of snails collected during the whole study.

In November 1996, the water level increased considerably, following rainfall, and the shore coincided with the original lake margins. Consequently, November and December 1996 were characterized by the water restoration of the lake and its recolonization by the gastropods, among them the amphibious species Lymnaea truncatula (explained $77.3 \%$ of the variance of the second axis), which was absent afterwards.

In May 1997, there was a great demographic explosion of freshwater gastropods (4,456 individuals), reflecting the breeding period and the successful recolonization of the lake by the whole molluscan community. This increase in gastropod numbers was not observed during the spring of 1998 and 1999, e.g. 75 and 82 individuals, respectively.

The great temporal variation of the snail populations correlated with different life-cycle patterns. Among the five dominant species in the gastropod community, $G$. albus, P. acuta, L. peregra and L. auricularia were present throughout the year during the whole study (FO $\geq 78 \%$, Table II), whereas P. planorbis was very restricted in time and disappeared completely during several months $(\mathrm{FO}=42 \%)$. In the case of $P$. planorbis, which explained $12.2 \%$ of the variance of the first axis and represented about $20 \%$ of the molluscan community, $90 \%$ of individuals were sampled in May 1997. Whatever the snail species, the main period of reproduction was the vernal season; a single breeding period characterized $P$. planorbis versus two or three periods for G. albus, P. acuta, L. peregra, and L. auricularia.

\section{STRUCTURE AND DYNAMICS OF THE TREMATODE COMMUNITY AND INTERACTIONS WITH THE GASTROPOD COMMUNITY}

Trematodes in the collective gastropod community

Ten morphological types of cercariae were distinguished among the gastropod host community of the Combourg lake (Table III). Of the total parasitic fauna, the cercariaeum was the most frequent $50 \%$ of the patent infrapopulations). Four types of furcocercariae, two echinostomes, two xiphidiocercariae and one notocotyle were also present. Trematode larvae, with a total prevalence of $2.0 \pm 0.3 \%$ (192 infected among 9,831 snails collected in 33 months), were detected among 14 of the 17 species of gastropods sampled; 16 individuals harboured immature cercariae. Among the three mollusc species not found infected during the study, $P$. acuta, a frequent species, was probably not an intermediate host for the trematodes present in the lake, whereas G. acronicus was too rare during the study $(0.1 \%$ of the sampled snails) to assert that it is not a possible snail host. Segmentina nitida was not found infected during this survey, but was found harbouring larval trematodes in previous studies (Gérard, 1997).

\begin{tabular}{|c|c|c|c|c|c|}
\hline Gastropods & $\mathbf{A}$ & F (\%) & FO $(\%)$ & NIS & $\mathbf{P}(\%)$ \\
\hline Valvata cristata (Vc) & 379 & $3.86 \pm 0.38$ & $78.79 \pm 19.50$ & 18 & $4.75 \pm 2.14$ \\
\hline Valvata pulchella (VPu) & 357 & $3.63 \pm 0.37$ & $30.30 \pm 21.92$ & 7 & $1.96 \pm 1.44$ \\
\hline Valvata piscinalis (Vpi) & 129 & $1.31 \pm 0.22$ & $57.58 \pm 23.57$ & 4 & $3.10 \pm 2.99$ \\
\hline Lymnaea truncatula $(\mathrm{Lt})$ & 41 & $0.42 \pm 0.13$ & $6.06 \pm 11.38$ & 1 & $2.44 \pm 4.72$ \\
\hline Lymnaea palustris (LPa) & 138 & $1.40 \pm 0.23$ & $54.55 \pm 8.67$ & 6 & $4.35 \pm 3.40$ \\
\hline Lymnaea peregra (Lpe) & 1,596 & $16.23 \pm 0.73$ & $93.94 \pm 11.38$ & 22 & $1.38 \pm 0.57$ \\
\hline Lymnaea auricularia (Lau) & 1,051 & $10.69 \pm 0.61$ & $78.79 \pm 19.50$ & 74 & $7.04 \pm 1.55$ \\
\hline Lymnaea stagnalis (Ls) & 19 & $0.19 \pm 0.09$ & $27.27 \pm 21.24$ & 1 & $5.26 \pm 10.04$ \\
\hline Gyraulus albus (Gal) & 2,389 & $24.30 \pm 0.85$ & $84.85 \pm 17.10$ & 29 & $1.21 \pm 0.44$ \\
\hline Gyraulus acronicus (Gac) & 12 & $0.12 \pm 0.07$ & $6.06 \pm 11.38$ & 0 & 0.00 \\
\hline Planorbis planorbis (Pp) & 1,903 & $19.36 \pm 0.78$ & $42.42 \pm 23.57$ & 19 & $1.00 \pm 0.45$ \\
\hline Planorbarius corneus $(P c)$ & 24 & $0.24 \pm 0.10$ & $21.21 \pm 19.50$ & 1 & $4.17 \pm 7.99$ \\
\hline Armiger crista $(A C)$ & 545 & $5.54 \pm 0.45$ & $51.52 \pm 23.84$ & 3 & $0.55 \pm 0.62$ \\
\hline Segmentina nitida $(S n)$ & 2 & $0.02 \pm 0.03$ & $3.03 \pm 8.18$ & 0 & 0.00 \\
\hline Hippeutis complanatus (Hc) & 54 & $0.55 \pm 0.15$ & $39.39 \pm 23.31$ & 2 & $3.70 \pm 5.04$ \\
\hline Ancylus lacustris (Al) & 76 & $0.77 \pm 0.17$ & $51.52 \pm 23.84$ & 5 & $6.58 \pm 5.57$ \\
\hline Physa acuta $(\mathrm{Pa})$ & 1,116 & $11.35 \pm 0.63$ & $78.79 \pm 19.50$ & 0 & 0.00 \\
\hline Total of gastropods & 9,831 & & & 192 & 1.95 \\
\hline
\end{tabular}

Table II. - Structure of the gastropod community and prevalence of trematodes in the Combourg Lake from September 1996 to May 1999 (A: abundance, F: frequency \pm SE, FO: mean frequency of occurrence per month \pm SE, NIS : number of infected snails, P: collective prevalence $\pm \mathrm{SE}$ (all trematodes)). 
The 197 trematode infrapopulations (192 infected snails of which five double infections) were unequally distributed among the gastropod community, with prevalences ranging between $7.0 \%$ for $L$. auricularia and $0.6 \%$ for Armiger crista (Table II). The two-way analysis of variance revealed significant effects of gastropod species $(P=0.0001)$, parasitism $(P=0.0003)$ and their interaction $(P=0.0064)$ on the shell size of the molluscs. For each gastropod species, infected snails were significantly larger than healthy snails. For the most abundant gastropods, mean sizes of infected versus healthy snails during the 33-month study were $3.9 \pm 0.5 \mathrm{~mm}$ us $3.1 \pm 0.1 \mathrm{~mm}$ for $G$. albus; $7.6 \pm$ $2.9 \mathrm{~mm}$ vs $4.7 \pm 0.1 \mathrm{~mm}$ for P. planorbis; $9.8 \pm 2.5 \mathrm{~mm}$ vs $5.2 \pm 0.2 \mathrm{~mm}$ for L. peregra, and $12.3 \pm 1.1 \mathrm{~mm}$ vs $6.4 \pm 0.3 \mathrm{~mm}$ for L. auricularia.

\section{Component communities}

Depending on the gastropod populations, the species richness of trematode component communities varied from a single type of larval trematode for Valvata pul- chella, V. piscinalis, Lymnaea truncatula, L. palustris, L. stagnalis, Ancylus lacustris, Planorbarius corneus, to seven cercarial types for G. albus and L. auricularia (Tables III, IV). Hierarchical clustering of host species based on their trematode fauna showed resemblances between L. peregra, L. auricularia and G. albus (five or six similar cercariae), and into a six species-group composed of L. palustris, L. truncatula, A. lacustris, and the three valvatid species, characterized by a high frequency of cercariaeum ranging from 94.4 to $100 \%$, and one or two types of infections.

\section{Infracommunities}

Numbers of trematode infracommunities and their species richness were very low. Only five $(2.6 \%$ of infected snails) multispecies parasite infections were detected, with a maximum of two species per host (Table V). Four were present in L. auricularia. Larval stages involved within the double infections were rediae-rediae (2), rediae-sporocysts (2), and sporocysts-sporocysts (1).

\begin{tabular}{|c|c|c|c|c|c|c|}
\hline Cercariae & $\begin{array}{l}\text { Intramolluscan } \\
\text { stages }\end{array}$ & Identification & NTI & FTI $(\%)$ & Host range & $\mathbf{S}$ \\
\hline cercariaeum & rediae & Asymphylodora sp. & 90 & $49.72 \pm 9.08$ & $\begin{array}{l}A c, A l, G a, H c, L a u, L p a, \\
L p e, L t, P p, V c, V p i, V p u\end{array}$ & 12 \\
\hline furcocercaria 1 & sporocysts & Tylodelphys sp. & 27 & $14.92 \pm 6.23$ & $A c, G a, L a u, L p e, L s$ & 5 \\
\hline echinostome 1 & rediae & Echinostomatidae & 20 & $11.05 \pm 5.47$ & Ga, Lau, Lpe & 3 \\
\hline furcocercaria 2 & sporocysts & Strigeoidea & 17 & $9.39 \pm 5.09$ & Ga, Lau, Lpe & 3 \\
\hline notocotyle & rediae & Notocotylus sp. & 11 & $6.08 \pm 4.16$ & Ga, Lau, Lpe & 3 \\
\hline xiphidiocercaria 1 & sporocysts & unknown & 7 & $3.87 \pm 3.35$ & Lau, Lpe & 2 \\
\hline furcocercaria 3 & sporocysts & Trichobilharzia sp. & 4 & $2.21 \pm 2.55$ & Ga, Lau & 2 \\
\hline xiphidiocercaria 2 & sporocysts & unknown & 3 & $1.66 \pm 2.22$ & $G a, P p$ & 2 \\
\hline echinostome 2 & rediae & Echinostomatidae & 1 & $0.55 \pm 1.29$ & $H c$ & 1 \\
\hline furcocercaria 4 & sporocysts & unknown & 1 & $0.55 \pm 1.29$ & $V c$ & 1 \\
\hline
\end{tabular}

Table III. - Structure of the larval trematode community (197 infrapopulations of which 16 prepatent infections not included here) in the Combourg Lake from September 1996 to May 1999 (NTI: number of patent trematode infrapopulations, FTI: frequency of patent trematode infrapopulations \pm SE, S: specificity $=$ number of intermediate host species). Abbreviations of host species are in Table II.

\begin{tabular}{|c|c|c|c|c|c|c|c|c|c|c|c|c|c|}
\hline Larval trematodes & Gal & Lau & Lpe & $P \boldsymbol{P}$ & $A c$ & Hc & $V c$ & Vpu & $V p i$ & $L t$ & Lpa & Ls & $\boldsymbol{A l}$ \\
\hline cercariaeum & 55.17 & 14.29 & 35.29 & 88.89 & 50.00 & 50.00 & 94.44 & 100.00 & 100.00 & 100.00 & 100.00 & & 100.00 \\
\hline furcocercaria 1 & 3.45 & 31.44 & 11.77 & & 50.00 & & & & & & & 100.00 & \\
\hline echinostome 1 & 3.45 & 24.28 & 11.77 & & & & & & & & & & \\
\hline furcocercaria 2 & 24.14 & 10.00 & 17.64 & & & & & & & & & & \\
\hline notocotyle & 6.90 & 8.57 & 17.64 & & & & & & & & & & \\
\hline xiphidiocercaria1 & & 7.14 & 5.88 & & & & & & & & & & \\
\hline furcocercaria 3 & 3.45 & 4.29 & & & & & & & & & & & \\
\hline xiphidiocercaria 2 & 3.45 & & & 11.11 & & & & & & & & & \\
\hline echinostome 2 & & & & & & 50.00 & & & & & & & \\
\hline furcocercaria 4 & & & & & & & 5.56 & & & & & & \\
\hline
\end{tabular}

* The single Planorbarius corneus found infected harboured immature rediae.

Table IV. - Trematode component communities in the Combourg Lake (Sept 1996 - May 1999): frequency of larval trematodes in infected snails of each host population (= number of snails infected by one trematode species $\mathrm{x} 100 /$ total number of infected snails) (prepatent infections not included*). Abbreviations of host species are in Table II. 


\begin{tabular}{lcc}
\hline \multicolumn{1}{c}{ Parasite association } & Host species & Larval stages \\
\hline echinostome 1/notocotyle & Lau & red-red \\
echinostome 1/notocotyle & Lau & red-red \\
echinostome 1/furcocercaria 1 & Lau & red-spo \\
cercariaeum /furcocercaria 2 & Lpe & red-spo \\
xiphidiocercaria 1/furcocercaria 2 & Lau & spo-spo \\
\hline
\end{tabular}

Table V. - Five trematode double infections among 192 infected snails in Combourg Lake (Sept 1996 - May 1999) (red = rediae, spo $=$ sporocysts). Abbreviations of host species are in Table II.

Infrapopulations and host specificity

Trematode larvae exhibit very different levels of host specificity (Tables III, IV). One furcocercaria (type 4) and one echinostome (type 2) were strictly specific for Valvata cristata and Hippeutis complanatus, respectively, whereas the cercariaeum was present in 12 different host species. There was a significant positive correlation (Spearman coefficient $=0.98 ; P=0.003$ ) between host specificity (S), e.g., number of first intermediate host species, and number of trematode infrapopulations of a species across all gastropod species (NTI), and between host specificity (S) and frequency of trematode infrapopulations of a species across all gastropod species (FTI). The regressions were: NTI $=8.04 \times \mathrm{S}-8.43$ and $\mathrm{FTI}=4.19 \times \mathrm{S}-4.39$.
Temporal fluctuations

Dynamics of the collective trematode prevalence in the host community ( $\%$ infected/collected snails belonging to species found infected per month), and the abundance of host gastropods were interacting (Fig. 1). The prevalence, equal to $0.3 \%$ in May 1997 (13 infected snails) during the gastropod demographic explosion (4,456 snails), reached a peak of $33.0 \%$ in September 1997 (33 infected snails) when the malacological community declined (278 snails). Depending on the time of collections and the snail species, the prevalence per host population (Table VI) varied enormously, from 0 to $100 \%$, with a mean value \pm SE of $7.1 \pm 3.0 \%$. For seven host species ( $V$. pulchella, V. piscinalis, L. peregra, L. auricularia, L. stagnalis, G. albus, P. corneus), the prevalence was $>50 \%$ several times during the study. The data on the host abundances and parasite prevalences of each of the 14 host species during 33 months were compared by a regression analysis. Abundance of a gastropod species was inversely related to its prevalence: $\mathrm{P}=15 \times 10^{-0.001 \mathrm{~A}}$ (Spearman coefficient $=0.51, P=0.0001, \mathrm{~N}=462$ ). When individual host species were considered (Table VII), this relationship held up for 10 species and was not significant $(P>0.05)$ for four species, e.g. V. piscinalis, $L$. peregra, L. stagnalis and $P$. corneus.



Fig. 1. - Temporal variation of the abundance of host gastropods (open circles) and the host prevalence of trematodes (closed circles) in the Combourg Lake from September 1996 to May 1999. 


\begin{tabular}{|c|c|c|c|c|c|c|c|c|c|c|c|c|c|c|c|c|c|}
\hline & & Sep-96 & Oct-96 & Nov-96 & Dec-96 & Jan-97 & Feb-97 & Mar-97 & Apr-97 & May-97 & Jun-97 & Jul-97 & Aug-97 & Sep-97 & Oct-97 & Nov-97 & Dec-97 \\
\hline Valvata cristata & & & & & 0 & & 0 & 0 & 0 & 0 & 0 & 10 & 0 & & 0 & 18.52 & 3.85 \\
\hline Valvata pulchella & & & & & & & & & & & 0 & 5.26 & & & & & 0 \\
\hline Valvata piscinalis & & 0 & 0 & & & & & & & 0 & 0 & 0 & 0 & 20.00 & & 0 & \\
\hline Lymnaea truncatula & & & & 6.67 & 0 & & & & & & & & & & & & \\
\hline Lymnaea palustris & & & & & 0 & 2.63 & 0 & 0 & 0 & 0 & 0 & 0 & 0 & 0 & & 30.77 & 0 \\
\hline Lymnaea peregra & & 0 & 0 & 0 & 1.61 & 1.72 & 0 & 0 & 0 & 0 & 0.81 & 7.14 & & 16.00 & & 44.44 & 0 \\
\hline Lymnaea auricularia & & & & & & & 8.33 & 0 & 0 & 0.44 & 1.47 & 2.30 & 60.00 & 45.76 & 0 & 2.41 & 6.45 \\
\hline Lymnaea stagnalis & & & & & & 0 & 0 & & & & 0 & & 0 & & & & 0 \\
\hline Gyraulus albus & & & & 0 & 0 & 0 & 0 & 0 & 0 & 0 & 0.36 & 4.69 & 19.05 & 0 & & 12.50 & 8.33 \\
\hline Planorbis planorbis & & & & & 0 & & 0 & 0 & 0 & 0.70 & 5.00 & 10.53 & 16.67 & & & 0 & 0 \\
\hline Planorbarius corneus & & & & & & & & & & & 0 & 0 & & 50.00 & & & \\
\hline Armiger crista & & & & & & & & & & 0 & 0.26 & 5.56 & & & & 0 & \\
\hline Hippeutis complanatus & & & & & & & & & & & 0 & 0 & 33.33 & 0 & & & \\
\hline \multirow[t]{2}{*}{ Ancylus lacustris } & & & & & & & & & 0 & & 0 & & 0 & & & 0 & 0 \\
\hline & Jan-98 & Feb-98 & Mar-98 & Apr-98 & May-98 & Jun-98 & Jul-98 & Aug-98 & Sep-98 & Oct-98 & Nov-98 & Dec-98 & Jan-99 & Feb-99 & Mar-99 & Apr-99 & May-99 \\
\hline V. cristata & 0 & 10.53 & 0 & 16.13 & 12.50 & & 0 & & 0 & 0 & 0 & 2.70 & 0 & 0 & 0 & 0 & 0 \\
\hline V. pulchella & & & 100.00 & 0 & 0 & & & & & 50.00 & & & & & 50.00 & 0 & 100.00 \\
\hline V. piscinalis & & & 0 & 0 & 50.00 & 0 & 0 & 0 & 33.33 & 50.00 & & & & 0 & 0 & 0 & \\
\hline L. truncatula & & & & & & & & & & & & & & & & & \\
\hline L. palustris & 25.00 & 0 & 0 & & 0 & 0 & & & & & & & & 0 & & & \\
\hline L. peregra & 5.56 & 0 & 10 & 33.33 & 0 & 0 & 0 & 0 & 0 & 0 & 11.11 & 10.00 & 0 & 0 & 0 & 100.00 & 0 \\
\hline L. auricularia & 0 & 5.36 & 13.64 & 0 & 0 & & 0 & 22.22 & 0 & 0 & 28.57 & 11.11 & 0 & 33.33 & & 20.00 & 0 \\
\hline L. stagnalis & & & 0 & & & 0 & & 100.00 & & & 0 & & & & & & \\
\hline G. albus & 100.00 & 0 & 20.00 & 20.00 & 0 & 0 & & & 0 & 0 & 0 & 25.00 & 0 & 0 & 0 & 22.22 & 0 \\
\hline P. planorbis & & 0 & 33.33 & & 0 & & & & & & & & & & & & 0 \\
\hline P. corneus & & & 0 & & 0 & & 0 & & & 0 & & & & & & & \\
\hline A. crista & & 0 & 0 & 0 & & 0 & & & 0 & 0 & 0 & 0 & 0 & 0 & 0 & 0 & 0 \\
\hline H. complanatus & & 0 & 0 & 0 & 25.00 & & 0 & & & & 0 & & & 0 & & 0 & 0 \\
\hline A. lacustris & 0 & 25.00 & 0 & 0 & 0 & & & & & & 25.00 & 0 & 22.22 & 0 & 0 & 0 & 0 \\
\hline
\end{tabular}

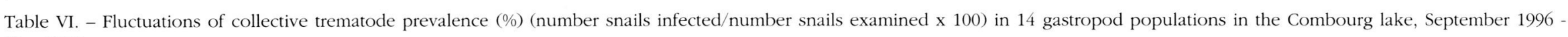
May 1999. 


\begin{tabular}{lcc}
\hline Host species & r & $\boldsymbol{P}$ \\
\hline Valvata cristata & 0.57 & 0.0012 \\
Valvata pulchella & 0.68 & 0.0001 \\
Valvata piscinalis & 0.26 & $0.1478^{*}$ \\
Lymnaea truncatula & 0.67 & 0.0001 \\
Lymnaea palustris & 0.41 & 0.0199 \\
Lymnaea peregra & 0.20 & $0.2631^{*}$ \\
Lymnaea auricularia & 0.58 & 0.0010 \\
Lymnaea stagnalis & 0.23 & $0.2028^{*}$ \\
Gyraulus albus & 0.38 & 0.0290 \\
Planorbis planorbis & 0.55 & 0.0017 \\
Planorbarius corneus & 0.31 & $0.0780^{*}$ \\
Armiger crista & 0.42 & 0.0163 \\
Hippeutis complanatus & 0.38 & 0.0325 \\
Ancylus lacustris & 0.43 & 0.0154 \\
\hline
\end{tabular}

* not significant $(\mathrm{P}>0.05)$.

Table VII. - Correlation coefficients (r) between gastropod abundance and collective prevalence for each host population in the Combourg lake from September 1996 to May 1999 ( sample size $=33$ ).

The great variability of the prevalence reflected temporal fluctuations of the different digenetic trematode populations (Table VIII). During the 33-month study, the mean $( \pm$ SE) infrapopulation number and species richness in the whole of the component trematode communities were $6.1 \pm 4.0$ infrapopulations and 2.2 \pm 1.0 species respectively. These two parameters varied from zero (in September-October 1996, MarchApril 1997, October 1997 and June-July 1998) to a maximum of 36 infrapopulations and seven species in summer 1997. Dynamics of the trematode populations allowed distinguishing a single permanent resident in the lake (autogenic species), the cercariaeum, observed in $70 \%$ of the samples. The nine other trematodes (furcocercariae, notocotyle, xiphidiocercariae and echinostome) were temporary residents (allogenic species).

\section{DISCUSSION}

\section{CHARACTERISTICS OF THE LARVAL TREMATODE COMMUNITY}

T The gastropod community of the Combourg lake was characterized by a high species richness (17 species with a mean of $8 \pm 1$ per month) compared with other sites, e.g. from one to 10 species with a mean of $4.2 \pm 2.2$ in 57 sites in eastern Brittany (Costil, 1994), from zero to 17 with a mean of $5.2 \pm$ 0.3 in 178 lakes in central North America (Pip, 1987), from one to six with a mean of $2.4 \pm 1.4$ in 158 ponds in Norway (Okland, 1990). Consequently, the Com- bourg lake offered a wide range of intermediate hosts for the trematode fauna. However, the species richness of the trematode collection in the whole gastropod community (10 species of cercariae) was not very high compared with other studies, e.g. nine cercarial species for seven gastropod species in the Albufera Natural Park (Spain) (Toledo et al., 1998), means of 12.3 trematode and six gastropod species in nine nonlacustrine habitats in Tanzania (Loker et al., 1981). Among the infected snails, prepatent infections were rare $(8.1 \%)$, probably due to the shorter duration of prepatency (a few weeks) versus patency (several months depending on the life-time of the snail), even if larval trematodes generally increased the mortality of their host.

Depending on the cercarial species, host specificity for the first intermediate host, usually quite strong (Esch \& Fernandez, 1994), was very different. In the Combourg lake, the most prevalent and successful trematode (cercariaeum) was a generalist infecting 12 species of snails. A significant positive relationship indicated that the frequency of a trematode species increased with the range of its snail hosts. This is in contrast with Adamson \& Caira (1994), who assumed that, even when specificity is primarily determined by ecological factors, adaptation to local conditions is expected to reinforce this specificity to the extent that the loss in fitness, due to decreased host range, is subsumed by gains made through more efficient use of the host. The degree of specificity a parasite exhibits is the result of an interplay of factors that act on various temporal scales, and it can be concluded that abiotic and biotic conditions in the freshwater ecosystem studied here (like high and stable molluscan species richness, wide fluctuations of gastropod abundance) favoured parasites with generalist versus specialist strategies.

Double infections were rare during the study $(2.6 \%$ of infected snails and $0.05 \%$ of collected snails), in agreement with the common report that fewer multispecies infections are observed than might be expected by chance (for reviews: Kuris \& Lafferty, 1994; Esch et al., 1997). The paucity of multispecies interactions is generally explained by competition, via a variety of interspecific competitive mechanisms depending on the type of interacting larval stages (sporocysts/rediae) and the dominance hierarchy at the infracommunity level (subordinate/dominant species). For example, rediae of many echinostome species fed on, and killed, rediae and sporocysts of subordinate species (Esch \& Fernandez, 1994). Kuris \& Lafferty (1994) estimated that $13 \%$ of trematode infections (especially subordinate species) were lost by interspecific interactions. However, Fernandez \& Esch (1991b) asserted that, under field conditions, the small number of multiple 


\begin{tabular}{|c|c|c|c|c|c|c|c|c|c|c|c|c|c|c|c|c|c|}
\hline & & Sep-96 & Oct-96 & Nov-96 & Dec-96 & Jan-97 & Feb-97 & Mar-97 & Apr-97 & May-97 & Jun-97 & Jul-97 & Aug-97 & Sep-97 & Oct-97 & Nov-97 & Dec-97 \\
\hline cercariaeum & & & & 1 & 1 & 1 & & & & 9 & 4 & 13 & 5 & 1 & & 11 & 6 \\
\hline furcocercaria 1 & & & & & & & & & & & 2 & & 7 & 13 & & 1 & 2 \\
\hline echinostome 1 & & & & & & 1 & & & & & & & 3 & 13 & & 1 & \\
\hline furcocercaria 2 & & & & & & & & & & & 2 & 7 & 1 & 2 & & 1 & \\
\hline notocotyle & & & & & & & & & & & & & & 5 & & 2 & 1 \\
\hline xiphidiocercaria 1 & & & & & & & & & & & & 1 & 1 & 1 & & & 1 \\
\hline furcocercaria 3 & & & & & & & & & & & & 1 & 3 & & & & \\
\hline xiphidiocercaria 2 & & & & & & & & & & 2 & & & & & & & \\
\hline echinostome 2 & & & & & & & & & & & & & & & & & \\
\hline furcocercaria 4 & & & & & & & & & & & & & & & & & \\
\hline immature sporocysts & & & & & & & 1 & & & 1 & & 2 & & & & & \\
\hline immature rediae & & & & & & & & & & 1 & & 3 & 2 & 1 & & & \\
\hline & Jan-98 & Feb-98 & Mar-98 & Apr-98 & May-98 & Jun-98 & Jul-98 & Aug-98 & Sep-98 & Oct-98 & Nov-98 & Dec-98 & Jan-99 & Feb-99 & Mar-99 & Apr-99 & May-99 \\
\hline cercariaeum & 2 & 3 & 10 & 6 & 3 & & & & 1 & 2 & 2 & 3 & 2 & & 1 & 2 & 1 \\
\hline furcocercaria 1 & & & & & & & & 1 & & & 1 & 1 & & & & & \\
\hline echinostome 1 & & 1 & 1 & & & & & & & & & & & & & & \\
\hline furcocercaria 2 & & & & & & & & 2 & & & & 1 & & & & & \\
\hline notocotyle & & 1 & & & & & & & & & & & & & & 2 & \\
\hline xiphidiocercaria 1 & & 1 & & 1 & & & & & & & & & & 1 & & & \\
\hline furcocercaria 3 & & & & & & & & & & & & & & & & & \\
\hline xiphidiocercaria 2 & & & & 1 & & & & & & & & & & & & & \\
\hline echinostome 2 & & & & & 1 & & & & & & & & & & & & \\
\hline furcocercaria 4 & & & & & 1 & & & & & & & & & & & & \\
\hline $\begin{array}{l}\text { immature sporocysts } \\
\text { immature rediae }\end{array}$ & 1 & & & & & & & & & & 4 & & & & & & \\
\hline
\end{tabular}

Table VIII. - Dynamics of the number of larval trematode infrapopulations in the Combourg Lake, September 1996 - May 1999. 
infections is related more directly to low host vagility and to several temporal and spatial factors external to the snail, for example, the temporal and spatial distribution of the parasites.

Among the ten species of cercariae in the Combourg lake, it seems that a single species (the cercariaeum Asymphylodora, a monorchiid parasite of freshwater fish) was autogenic (permanent species with entire life cycle within the aquatic ecosystem) and nine allogenic (life cycle including temporary vertebrate host species) sensu Esch et al. (1990). The relative richness in allogenic species may be linked to the diversity of potential vertebrate visitors, e.g. migrant waterfowl frequent in the region (definitive hosts of Tylodelphys sp., Notocoylus sp., Trichobilharzia sp., and most echinostomatids and strigeids), as well as the great temporal heterogenenity of gastropod abundance in the lake. Whatever the trematode species, important seasonal variations were always observed, even if greater in the case of allogenic versus autogenic species. These variations were not only related to the wide fluctuations of the gastropod community, but also, according to numerous authors (Erasmus, 1972; Fernandez \& Esch, 1991a; Williams \& Esch, 1991), to spatio-temporal heterogeneity in habitat structure, distribution and abundance of infective stages, dynamics of the first intermediate host population, and behaviour of definitive and second intermediate hosts.

ECOLOGICAL INFLUENCE OF INDIVIDUAL GASTROPOD SPECIES ON THEIR RESPECTIVE TREMATODE COMMUNITIES AND INFECTION PATTERNS

All the gastropod species have not the same probability of becoming infected, not only because of the spatial and temporal heterogeneity in the distribution and abundance of trematode infective stages, but also because of the differences in their life-cycles and lifehistory traits, e.g. size, short/long-lived snails, semel/iteroparity, seasonal pattern of abundance, vagility, ecological habits, distribution in the aquatic habitat. These differences might be driving the differences in distribution of trematode infections in snails.

Among the two gastropod species never found infected was an abundant species present all the year in the lake, P. acuta, and belonging yet to one of the main families harbouring trematodes (Ewers, 1964). In Spanish marshes where P. acuta was also abundant and the most frequently occuring snail, Toledo et al. (1998) found only one parasitized among 2,717 individuals. These results were in contrast with that obtained for another physid species, in Charlie's pond, North Carolina, where a fifth of Physa gyrina harboured trematodes (Brown et al., 1988). A comparison by Snyder \& Esch (1993) of the trematode communities in two sympatric pulmonates, P. gyrina and Helisoma anceps, revealed that the trematode dynamics are different in ways that can be attributed to different host life-histories.

In general, in Combourg lake, prevalence and parasite diversity increase rapidly after the establishment of a new host cohort, and high prevalences were observed for small sample sizes and old/large individuals. Among the molluscan community, resemblances between $L$. auricularia, $L$. peregra and $G$. albus were demonstrated based on their susceptibility to numerous trematode species (6-7 versus 1-2 for the other host species) and the assemblage of larval digeneans they hosted (5-6 similar species). These three pulmonates belong to the main families (Planorbidae and Lymnaeidae) harbouring trematodes (Ewers, 1964; Erasmus, 1972) and were frequently occurring in the gastropod community. They are semelparous and annual with a spring breeding season, but, partly due to the existence of microgeographical races and depending on the nature of the freshwater habitat, intraspecific variations are frequent in life-cycles with two or three breeding periods. Resemblances between $L$. auricularia and L. peregra, based on their parasitic fauna, were also demonstrated in the U. K. by Adam \& Lewis (1993), but not between these two lymneids and G. albus. In Spain, L. auricularia and L. peregra were coexisting (Toledo et al., 1998), but L. auricularia (0.1\% of snails sampled) was never infected, whereas $L$. peregra (the most abundant species with $38.1 \%$ of snails sampled) harboured four cercarial species. According to these results, the existence of resemblances in trematode component communities seems to depend mainly on the environmental conditions in a given freshwater ecosystem, that influence the life cycles patterns of gastropods. Moreover, similarity in molluscan faunas does not necessarily imply similarity in parasite faunas.

\section{PARASITE IMPACT ON THE FRESHWATER GASTROPOD COMMUNITY}

Due to the instability and stressful nature of their habitat, freshwater organisms show considerable variations in their population dynamics and community structure, as well as in their life-history patterns (RusselHunter, 1961; Calow, 1978; Brown, 1985). In the Combourg lake, a great part of the variability in the malacofauna at the beginning of the study can be explained by the unusual severe drought of summer 1996, and according to the multivariate analysis, time and rainfall seemed to be the major factors controlling gastropod assemblages. However, if the structure and dynamics of gastropod communities are mainly linked to the variability of environmental conditions, they can also be influenced by biotic factors like parasitism. Larval trematodes generally induce castration and an increased mortality in their molluscan intermediate 
host and moreover, they may affect the host competitive abilities and foraging behavior (see Introduction). Among the 17 gastropod species living in the lake, 15 were host species and trematodes infected up to $100 \%$ of snails in some cases ( $V$. pulchella, L. peregra, L. stagnalis, G. albus) on a seasonal basis (Table VI).

Whatever the host species, the size of infected snails was greater than that of healthy snails as shown in other field studies (Crews \& Esch, 1986; Goater et al., 1989; Jokela \& Lively, 1995; Curtis, 1997). According to Sousa (1983) and Gérard \& Theron (1997), the influence of trematodes on the growth of freshwater snails is age/size-specific, and the growth rate of uninfected ones is generally similar or faster than that of infected. The phenomenon of enhanced growth, termed "gigantism", as seen in laboratory studies and described only in some trematode-mollusc systems (MacClelland \& Bourns, 1969; Cheng, 1971; Wilson \& Denison, 1980), was not observed under field conditions (Fernandez \& Esch, 1991a; Mouritsen \& Jensen, 1994; Curtis, 1995), except for Hydrobia spp. infected by a microphallid or Crytocotyle sp. (Gorbushin, 1997). As suggested by several authors (Sousa, 1983; Anderson \& Crombie, 1984; Curtis, 1996), the greater size of infected snails demonstrated in the present study is probably related to the fact that they are the oldest of the population and have, therefore, had the longest exposure time to infective miracidia.

The negative association between the density of gastropods and the prevalence of larval trematodes, suggested by Lafferty (1993) for Cerithidea californica, was demonstrated through a significant regression by Gérard (1997) for the molluscan community of the Combourg lake (1,365 snails collected in December 1994 and March 1995). In agreement with previous results, data obtained during 33 months confirm the existence of a significant negative correlation between the abundance of gastropod species and the prevalence. This relation can be interpreted in several ways. The fact that collective trematode prevalence was low when snail abundance was high (May 1997), and high when snail abundance was low (September 1997) could be taken as evidence that infected snails tended to survive better than uninfected, even if trematodes generally induce an increased mortality in their molluscan host. One can imagine that the decrease of snail abundance was partly linked to an environmental change, like pollution, and that infected versus healthy snails had a better resistance. Pollutants tend to influence parasitism in multiple ways, and in some cases, may increase the prevalence of trematodes (for reviews: Möller, 1987; Khan \& Thulin, 1991; Lafferty, 1997). However, it is evident as well, that the decrease of snail abundance after the spring breeding season and the demographic explosion was mostly explained by the great mortality of neonates and juveniles, that characterizes most temperate freshwater gastropods. Then, the concomitant increase of infected snail number may be interpreted as increasing acquisition of parasites over time.

Moreover, this relation suggests also the potential structuring force of larval trematodes on the snail host community, and then, on competitive interactions between infected and uninfected populations, and between infected populations depending on their parasite burden. Among the most abundant gastropod species and the most frequently occurring snails (FO $>50 \%$ ), V.piscinalis and L. peregra were the only species for which snail abundance and prevalence were independant (Table VII), as well as the only species present in the lake during the drought. $V$. piscinalis was a rare species except during the drought period (dominant species in September-October 1996); in contrast, L. peregra, described as ubiquitous, is characterized by the greater ecological amplitude and environmental tolerance (phenotypic plasticity) compared with the remaining species. For the other gastropods (G. albus, P. planorbis, L. auricularia, V. cristata, L. palustris, A. crista and A. lacustris), abundance was inversely correlated to prevalence, and one can envisage a regulator impact of larval trematodes on their snail host population. Consequences of trematode impact may be particularly important for the competition between L. auricularia, the most parasitized species, and $L$. peregra, the most frequently occurred, according to the usual lack of coexistence of these two species (Adam \& Lewis, 1992) and the fact that in the Combourg lake where they were coexisting, their population densities were on the whole inversely related. The freshwater environment represents a multifactorial system where the effect of one factor or parameter is often modified by other factors or conditions. Diversity and abundance of the snail fauna are related to various environmental parameters including parasitism. To measure more precisely the impact of larval trematodes on dynamics of snail host populations and their structuring force on gastropod communities, it would be of interest to compare molluscan faunas of ecosystems differing for the digeneans occurrence and analyse long-term changes in the interacting host-parasite assemblages.

\section{ACKNOWLEDGEMENTS}

T thank Dr Agnès Coutellec, Dr André Théron and Dr Jean-Pierre Pointier for their valuable comments and criticism. 


\section{REFERENCES}

ADAM M.E. \& LEWIS J.W. The lack of coexistence between Lymnaea peregra and Lymnaea auricularia (Gastropoda: Pulmonata). Journal of Molluscan Studies, 1992, 58, 227231.

ADAM M.E. \& LEWIS J.W. The role of Lymnaea auricularia (Linnaeus) and Lymnaea peregra (Müller) (Gastropoda: Pulmonata) in the transmission of larval digeneans in the lower Thames valley. Journal of Molluscan Studies, 1993, 57, 1-6.

ADAmSOn M.L. \& CAIRA J.N. Evolutionary factors influencing the nature of parasite specificity. Parasitology, 1994, 109, $85-95$.

ANDERSON R.M. \& MAY R.M. Regulation and stability of hostparasite interactions I. Regulatory processes. Journal of Animal Ecology, 1978, 47, 219-247.

Anderson R.M. \& Crombie J. Experimental studies of age-prevalence curves for Schistosoma mansoni infections in populations of Biomphalaria glabrata. Parasitology, 1984, 89, 79-104.

BROwN K.M. Intraspecific life history variation in a pond snail: the roles of population divergence and phenotypic plasticity. Evolution, 1985, 39, 387-395.

Brown K.M., Leathers B.K. \& Minchella D.J. Trematode prevalence and the population dynamics of freshwater pond snails. The American Midland Naturalist, 1988, 120, 289301.

Bush A.O., Lafferty K.D., Lotz J.M. \& Shostak A.W. Parasitology meets ecology on its own terms: Margolis et al. revisited. Journal of Parasitology, 1997, 83, 575-583.

CALOW P. The evolution of life-cycle strategies in freshwater gastropods. Malacologia, 1978, 17, 351-364.

Cheng T.C. Enhanced growth as a manifestation of parasitism and shell deposition in parasitized molluscs, in: Aspects of the biology of symbiosis. Cheng T.C. (ed), University Park Press, Baltimore, Maryland, 1971, 103-137.

Costil K. Freshwater gastropod communities in eastern Brittany (France). Journal of Molluscan Studies, 1994, 60, 467-471.

Crews A.E. \& Esch G.W. Seasonal dynamics of Halipegus occidualis (Trematoda: Hemiuridae) in Helisoma anceps and its impact on fecundity of the snail host. Journal of Parasitology, 1986, 72, 646-651.

CuRTIS L.A. Growth, trematode transmission, and longevity of a long-lived marine gastropod (Ilyanassa obsoleta). Journal of Marine Biology Assay U.K., 1995, 75, 913-925.

CURTIS L.A. The probability of marine gastropods being infected by a trematode. Journal of Parasitology, 1996, 82, 830-833

CuRTis L.A. Ilyanassa obsoleta (Gastropoda) as a host for trematodes in Delaware estuaries. Journal of Parasitology, 1997, 83, 793-803.

DE Kock K.N. The effect of exposure to Schistosoma mansoni on mortality rates of cohorts of different ages of Biomphalaria pfeifferi. Folia Parasitologica, 1993, 40, 9-12.
DOBSON A.P. \& HUDSON P.J. Regulation and stability of a freeliving host-parasite system: Trichostrongylus tenuis in red grouse. II. Population models. Journal of Animal Ecology, 1992, 61, 487-498.

Erasmus D.A. The biology of trematodes. Edward Arnold publishers, 1972, $312 \mathrm{p}$.

Esch G.W., Bush A. \& Aно J. Parasite communities: Patterns and processes. Chapman and Hall, London (U.K.), 1990, $335 \mathrm{p}$.

EsCh G.W. \& Fernandez J.C. Snail-trematode interactions and parasite community dynamics in aquatic systems: a review. The American Midland Naturalist, 1994, 131, 209-237.

Esch G.W., Wetzel E.J., Zelmer D.A. \& Schotthoefer A.M. Long-term changes in parasite population and community structure: a case history. The American Midland Naturalist, 1997, 137, 369-387.

EWERS W.H. An analysis of the molluscan hosts of the trematodes of birds and mammals and some speculations on host-specificity. Parasitology, 1964, 54, 571-578.

Fernandez J. \& Esch G.W. Effect of parasitism on the growth of the pulmonate snail Helisoma anceps. Journal of Parasitology, 1991a, 77, 937-944

FERNANDEZ J. \& EsCH G.W. Guild structure of larval trematodes in the snail Helisoma anceps: Patterns and processes at the individual host level. Journal of Parasitology, 1991b, 77, 528-539.

GÉRARD C. Importance du parasitisme dans la communauté de Gastéropodes de l'étang de Combourg (Bretagne, France). Parasite, 1997, 4, 49-54

Gérard C. \& Théron A. Age/size- and time-specific effects of Schistosoma mansoni on energy allocation patterns of its snail host Biomphalaria glabrata. Oecologia, 1997, $112,447-452$.

Goater T.M., Shostak A.W., Williams J.A. \& Esch G.W. A mark-recapture study of trematode parasitism in overwintered Helisoma anceps (Pulmonata), with special reference to Halipegus occidualis (Hemiuridae). Journal of Parasitology, 1989, 75, 553-560.

Gorbushin A.M. Field evidence of trematode-induced gigantism in Hydrobia spp. (Gastropoda: Prosobranchia). Journal of the Marine Biological Association of the United Kingdom, 1997, 77, 785-800.

Holmes J.C. Impact of infectious disease agents on the population growth and geographical distribution of animals, in: Population biology of infectious diseases. Anderson R.M. \& May R.M. (eds.), Springer-Verlag, New York (U.S.A.), 1982, 37-51.

Hurd H. Physiological and behavioural interactions between parasites and invertebrate hosts. Advances in Parasitology, 1990, 29, 271-318.

Jokela J. \& C. Lively M. Spatial variation in infection by digenetic trematodes in a population of freshwater snails (Potamopyrgus antipodarum). Oecologia, 1995, 103, 509-517.

Keymer A.E., Gregory R.D., Harvey P.H., Read A.F. \& SkorPING A. Parasite-host ecology: case studies in population dynamics, life-history evolution and community structure. Acta Oecologica, 1991, 12, 105-118. 
KHAN R.A. \& THulin J. Influence of pollution on parasites of aquatic animals. Advances in Parasitology, 1991, 30, 201238.

Kuris A.M. \& LAFFERTY K.D. Community structure: larval trematodes in snail hosts. Anmual review of ecology and systematics, 1994, 25, 189-217.

LAFFERTY K.D. Effects of parasitic castration on growth, reproduction and population dynamics of the marine snail Cerithidea californica. Marine Ecology Progress Series, 1993, 96, 229-237.

LAFFERTY K.D. Environmental parasitology: what can parasites tell us about human impacts on the environment? Parasitology Today, 1997, 13, 251-255.

Legendre L. \& Legendre P. Ecologie numérique. Tome 2. La structure des données écologiques. Masson, Paris (France), 1979, 247 p.

Loker E.S., Moyo H.G. \& Gardner S.L. Trematode-gastropod associations in nine none-lacustrine habitats in the Mwanza region in Tanzania. Parasitology, 1981, 83, 381-399.

LozANO G.A. Optimal foraging theory: a possible role for parasites. Oikos, 1991. 60, 391-395.

Mac Clelland G. \& Bourns T.K.R. Effect of Trichobilharzia ocellata on growth, reproduction and survival of Lymnaea stagnalis. Experimental Parasitology, 1969, 24, 137-146.

Möller H. Pollution and parasitism in the aquatic environment. International Journal for Parasitology, 1987, 17, 353362 .

Mouritsen K.N. \& Jensen K.T. The enigma of gigantism: effect of larval trematodes on growth, fecundity, egestion and locomotion in Hydrobia ulvae (Pennant) (Gastropoda: Prosobranchia). Journal of Experimental Marine Biology and Ecology, 1994, 181, 53-66.

OKLAND J. Lake and snails. Universal Book Services, Oegstgeest (The Netherlands), 1990, 516 p.

PIP E. Species richness of freshwater gastropod communities in central North America. Journal of Molluscan Studies, 1987, 53, 163-170.

Price P.W., Westoby M., Rice B., Atsatt P.R., Fritz R.S., Thompson J.N. \& Mobley K. Parasite mediation in ecological interactions. Annual Revue of Ecological System, $1986,17,487-505$.

Price P.W., Westoby M. \& Rice B. Parasite-mediated competition: some predictions and tests. The American Naturalist, 1988, 131, 544-555.

Russel-Hunter R. Annual variations in growth and density in natural populations of freshwater snails in the West Scotland. Proceedings of the Zoological Royal Society of London, 1961, 137, 219-253.

SNYDER S.D. \& Esch G.W. Trematode community structure in the pulmonate snail Physa gyrina. Journal of Parasitology, 1993, 79, 205-215.

SousA W.P. Host life history and the effect of parasitic castration on growth: a field study of Cerithidea californica Heldeman (Gastropoda: Prosobranchia) and its trematode parasites. Journal of Experimental Marine Biology and Ecology, 1983, 73, 273-296.
Thompson S.N. Review: Metabolic integration during the host associations of multicellular animal endoparasites. Comparative Biochemistry Physiology, 1985, 81B, 21-42.

Toledo R., Munoz-Antoli C., Perez M. \& Esteban J.G. Larval trematode infections in freshwater gastropods from the Albufera Natural Park in Spain. Journal of Helminthology, 1998, 72, 79-82.

Williams J.A. \& Esch G.W. Infra- and component community dynamics in the pulmonate snail Helisoma anceps, with special emphasis on the hemiurid trematode Halipegus occidualis. Journal of Parasitology, 1991, 77, 246-253.

Wilson R.A. \& DENison J. The parasitic castration and gigantism of Lymnaea truncatula infected with larval stages of Fasciola hepatica. Zeitschrift für Parasitenkunde, 1980, 61, 109-119.

Reçu le 10 février 2001 Accepté le 29 juin 2001 